\title{
CORRELATION ANALYSIS BETWEEN THE MORPHOMETRIC CHARACTERISTICS OF THE HEAD OF NUCLEUS CAUDATUS AND THE INTENSITY OF PSYCHOTIC MANIFESTATION IN SCHIZOPHRENIA
}

\author{
Stojanovic Zlatan, ${ }^{1}$ Stojanovic Vukadinovic Sanja, ${ }^{2}$ Macanovic Gordana ${ }^{3}$ \\ ${ }^{1}$ University of Banja Luka, Faculty of Medicine, Department for Anatomy, RS, Bosnia and Herzegovina \\ ${ }^{2}$ University Clinical Centre of the Republic of Srpska, Clinic for Psychiatry, Banja Luka, Bosnia and Herzegovina \\ ${ }^{3}$ College for the Education of Teachers, Sremska Mitrovica, Republic of Serbia
}

Primljen/Received 16. 04. 2018. god.

Abstract: Introduction: One of the significant functional disorders of the central nervous system in patients with schizophrenia is the increased activity of the mesolimbic dopaminergic system. By the nigrostriatal pathway, the caudate nucleus is closely related to other dopaminergic systems of the brain. Since the function of caudate nucleus relies on the action of dopamine in the brain; the role of this anatomical structure in the pathogenesis of schizophrenia is not sufficiently clarified. The aim of this paper was to examine whether the caudate nucleus participates in the modulation of the intensity of psychotic manifestations in schizophrenia. Patients and Methods: The study included a total of thirty-one patients with schizophrenia. Diagnosis of the schizophrenia was based on the DSM-IVcriterion (Diagnostic and Statistical Manual of Mental Disorders, fourth edition), and the intensity of psychotic manifestations was evaluated by using Brief Psychiatric Rating Scale (BPRS). The size of the caudate nucleus was determined on axial non-contrast CT images on the surface of the largest cross-section using AutoCAD 2007 digital morphometry. The statistical data were processed by the SPSS 16.0 program package. The statistical conclusions are presented on the basis of two-tail $p<0.05$. Results: In this study, we have observed a negative correlation between the area as well as the perimeter of the left caudate nucleus head section and the intensity of the psychotic manifestations (area: regression coefficient $\mathrm{B}=-0.17, \mathrm{p}=0.050$, perimeter: regression coefficient $\mathrm{B}=-0.010, \mathrm{p}=$ 0.012 ). On the right hemisphere of the brain we observed only a negative correlation of the intensity of the
Prihvaćen/Accepted 10. 06. 2018. god.

psychotic manifestations from the perimeter of the head section of caudate nucleus (regression coefficient $\mathrm{B}=-0.013, \mathrm{p}=0.011)$. Conclusion: In our research we found that the higher intensity of psychotic manifestations in schizophrenia was accompanied with the smaller area and the perimeter of left caudate head as well as the smaller perimeter of the head of right caudate nucleus. The finding of the dependence of the intensity of psychotic manifestations on the perimeter of the right caudate head and not on its area speaks in favor of the caudate head surface deformations as one of the markers of intensity of psychotic manifestations in patients with schizophrenia.

Key words: caudate nucleus, schizophrenia, analysis, correlation.

\section{INTRODUCTION}

One of the significant functional disorders of the central nervous system in patients with schizophrenia is the increased activity of the mesolimbic dopaminergic system $(1,2)$. Caudate nucleus belongs to the subcortical gray masses of the brain i.e.to basal ganglia. By the nigrostriatal pathway, the caudate nucleus is closely related to other dopaminergic systems of the brain. Since the function of caudate nucleus relies on the action of dopamine in the brain; the role of this anatomical structure in the pathogenesis of schizophrenia is not sufficiently clarified. The aim of this paper was to examine whether the caudate nucleus participates in the modulation of the intensity of psychotic manifestations in schizophrenia. 


\section{PATIENTS AND METHODS}

The study encompassed a total of thirty-one persons with schizophrenia (F20): 15 females and 16 males. Schizophrenia diagnosis was based on the DSM-IV criterion (3), and the intensity of psychotic manifestations was evaluated using the Brief Psychiatric Rating Scale (BPRS) (4). The intensity of psychotic manifestations in this scale is scored by the values from 1 to $7(1=$ symptoms not present, 2 = very mild, $3=$ mild, $4=$ moderate, $5=$ moderately strong, $6=$ strong and $7=$ extremely strong). More BPRS score values reflect higher intensity of the psychotic manifestations.

The size of the caudate nucleuswas determined on axial non-contrast CT images (layer thickness of $5 \mathrm{~mm}$ ) on the surface of the largest cross section. The area and the perimeter of the caudate head were determined using the AutoCAD digital planimetry ( $\mathrm{Fi}$ gure 1). AutoCAD 2007 for PC Windows (developed by Autodesk, Inc. San Rafael, California, U.S.) belongs to a group of software packages designed for drawing, designing and other aspects of computer application engineering practice. This software package can also be used to measure surfaces of irregular geometric figures, such as central nervous system structures (5).

Patients with severe comorbid states (cardiac decompensation, unstable angina pectoris, myocardial infarction in the previous and the year of the study, infectious diseases, malignant and chronic immune diseases) were excluded from the study because of the confounding effect. Also, the study did not include patients with other psychiatric disorders diagnoses, neurological disorders and patients with the history of stroke.

The statistic data are processed in the SPSS 16.0 program package. The hypotheses of the regression

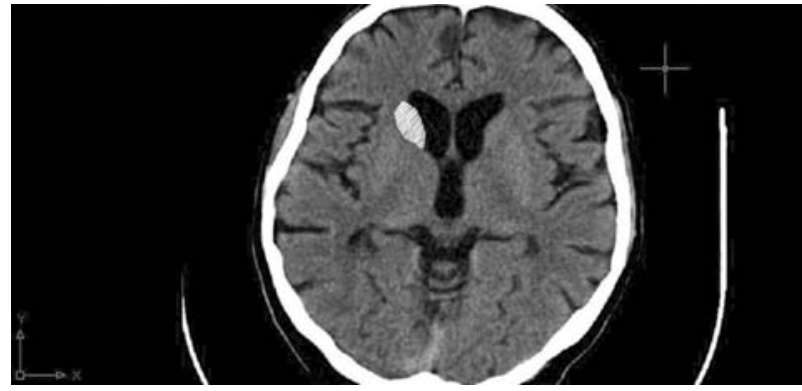

Figure 1. Display of the AutoCAD digital morphometry of the largest cross-section of the right caudate nucleus head: area $141.18 \mathrm{~mm} 2$, perimeter $48.802 \mathrm{~mm}$

models used were tested. The statistical conclusions are presented on the basis of two-tail $\mathrm{p}<0.05$.

\section{RESULTS}

Examination of the correlationbetween intensity of psychotic manifestations in patients with schizophrenia comparing the gender and age of respondents is shown in Table 1.

Since the deviation of BPRS scores from the normal distribution was observed (Shapiro-Wilk test $p=$ $0.044)$, in the correlation of psychotic manifestations intensityregarding the gender and age of respondents the generalized linear model of the subclass gamma with the log link (robust estimator) was used. Negative correlation i.e. higher intensity of symptoms of psychotic manifestations in younger personswas observed(regression coefficient $B=-0.00036, p<0.001$ ) (Table 1). By incorporating only one parameter i.e. age of the respondents in the examined model, the aforementioned correlation was also confirmed (regression coefficient $\mathrm{B}=-0.00040, \mathrm{p}<0.001$ ).

Examining the correlation of the intensity of psychotic manifestations (BPRS score) of patients with

Table 1. Dependence of the intensity of psychotic manifestations of patients with schizophrenia regarding the gender and the age of respondents

\begin{tabular}{|c|c|c|c|c|c|c|c|}
\hline \multicolumn{3}{|c|}{ Parameter } & \multirow{2}{*}{ B Standard Error } & $95 \%$ Wald Confidence Interval & \multicolumn{3}{|c|}{ Hypothesis Test } \\
\cline { 4 - 8 } & & & Lower & Upper & Wald Chi-square & $\mathrm{df}$ & $\mathrm{p}$ \\
\hline (Intercept) & 4.254 & 0.0530 & 4.150 & 4.358 & 6433.764 & 1 & $<0.001$ \\
\hline Years & -0.00036 & 0.00009 & -0.0005 & -0.0002 & 16.217 & 1 & $<0.001$ \\
\hline [Male] & 0.075 & 0.0738 & -0.069 & 0.220 & 1.042 & 1 & 0.307 \\
\hline [Female] & $0^{\mathrm{a}}$ & & & & & & \\
\hline (Scale) & $0.045^{\mathrm{b}}$ & & & & & & \\
\hline
\end{tabular}

BPRS: Brief Psychiatric Rating Scale Dependent Variable: BPRS score

a. This parameter is set to zero because it is redundant.

b. Calculation based on thePearson's Chi-Squared test. 
Table 2. Examination of the dependency of the intensity of psychotic manifestations from the largest cross section area of the left caudate nucleus head

\begin{tabular}{|c|c|c|c|c|c|c|c|}
\hline \multicolumn{8}{|c|}{ Parameter Estimates } \\
\hline \multirow{2}{*}{ Parameter } & \multirow{2}{*}{ B } & \multirow{2}{*}{$\begin{array}{l}\text { Standard } \\
\text { Error }\end{array}$} & \multicolumn{2}{|c|}{$\begin{array}{l}\text { 95\% Wald Confidence } \\
\text { Interval }\end{array}$} & \multicolumn{3}{|c|}{ Hypothesis Test } \\
\hline & & & Lower & Upper & $\begin{array}{c}\text { Wald } \\
\text { Chi-Square }\end{array}$ & $\mathrm{df}$ & $\mathrm{p}$ \\
\hline (Intercept) & 6.631 & 1.2016 & 4.276 & 8.986 & 30.453 & 1 & $<0.001$ \\
\hline Years & -0.054 & 0.0291 & -0.111 & 0.003 & 3.429 & 1 & 0.064 \\
\hline $\begin{array}{l}\text { Cross-sectional area of the left caudate } \\
\text { head }\left(\mathrm{mm}^{2}\right)\end{array}$ & -0.017 & 0.0087 & -0.034 & -0.00004 & 3.858 & 1 & 0.050 \\
\hline $\begin{array}{l}\text { Years *Cross sectional area of the left } \\
\text { caudate head }\end{array}$ & 0.00039 & 0.0002 & -0.00003 & 0.001 & 3.370 & 1 & 0.066 \\
\hline (Scale) & $0.042^{\mathrm{a}}$ & & & & & & \\
\hline
\end{tabular}

BPRS: Brief Psychiatric Rating Scale

Dependent Variable: BPRS score

a. Calculation based on thePearson's Chi-Squared test.

Table 3. Examination of the dependency of the intensity of psychotic manifestations from the largest cross section perimeter of the left caudate nucleus head

\begin{tabular}{|c|c|c|c|c|c|c|c|}
\hline \multicolumn{8}{|c|}{ Parameter Estimates } \\
\hline \multirow{2}{*}{ Parameter } & \multirow{2}{*}{ B } & \multirow{2}{*}{$\begin{array}{l}\text { Standard } \\
\text { Error }\end{array}$} & \multicolumn{2}{|c|}{$\begin{array}{l}\text { 95\% Wald Confidence } \\
\text { Interval }\end{array}$} & \multicolumn{3}{|c|}{ Hypothesis Test } \\
\hline & & & Lower & Upper & $\begin{array}{c}\text { Wald } \\
\text { Chi-Square }\end{array}$ & $\mathrm{df}$ & $\mathrm{p}$ \\
\hline (Intercept) & 4.747 & 0.1950 & 4.365 & 5.129 & 592.721 & 1 & $<0.001$ \\
\hline Years & -0.00047 & 0.00008 & -0.0006 & -0.0003 & 37.224 & 1 & $<0.001$ \\
\hline $\begin{array}{l}\text { Cross-sectional perimeter of the left } \\
\text { caudate head }(\mathrm{mm})\end{array}$ & -0.010 & 0.0038 & -0.017 & -0.002 & 6.357 & 1 & 0.012 \\
\hline (Scale) & $0.042^{\mathrm{a}}$ & & & & & & \\
\hline
\end{tabular}

BPRS: Brief Psychiatric Rating Scale

Dependent Variable: BPRS score

a. Calculation based on thePearson's Chi-Squared test.

schizophrenia and the age and the area of the largest cross section of the left caudate nucleus head we found greater intensity of psychotic manifestations in persons with smaller caudate head area (regression coefficient $B$ $=-0.17, p=0.050)$ (Table 2). For the examination of statistical significance, the generalized linear model of the subclass gamma with the log link (robust estimator) was used.

Examining the correlation between intensity of psychotic manifestations (BPRS score) of patients with schizophrenia and the age and the perimeter of the largest cross section of the left caudate nucleus head we found greater intensity of psychotic manifestations in younger persons (regression coefficient $B=-0.00047, p$ $<0.001$ ) with smaller caudate head perimeter (regression coefficient $B=-0.010, p=0.012$ ) (Table 3$)$. For the examination of statistical significance, the generalized linear model of the subclass gamma with the log link (robust estimator) was used.

Examining the correlation between the intensity of psychotic manifestations (BPRS score) of patients with schizophrenia and the age and the area of the largest cross section of the right caudate nucleus head we did not certain correlation between the intensity of psychotic manifestations and caudate head area (regression coefficient $\mathrm{B}=-0.002, \mathrm{p}=0.404$ ) (Table 4). For the examination of statistical significance, the generalized linear model of the subclass gamma with the log link (robust estimator) was used.

Examining the correlation between the intensity of psychotic manifestations (BPRS score) of patients with schizophrenia and the age and the perimeter of 
Table 4. Examination of the dependency of the intensity of psychotic manifestations from the largest cross section area of the right caudate nucleus head

\begin{tabular}{|c|c|c|c|c|c|c|c|}
\hline \multicolumn{8}{|c|}{ Parameter Estimates } \\
\hline \multirow{2}{*}{ Parameter } & \multirow{2}{*}{ B } & \multirow{2}{*}{$\begin{array}{l}\text { Standard } \\
\text { Error }\end{array}$} & \multicolumn{2}{|c|}{$\begin{array}{l}\text { 95\% Wald Confidence } \\
\text { Interval }\end{array}$} & \multicolumn{3}{|c|}{ Hypothesis Test } \\
\hline & & & Lower & Upper & $\begin{array}{c}\text { Wald } \\
\text { Chi-Square }\end{array}$ & $\mathrm{df}$ & $\mathrm{p}$ \\
\hline (Intercept) & 4.640 & 0.4095 & 3.837 & 5.443 & 128.398 & 1 & $<0.001$ \\
\hline Years & -0.0005 & 0.000084 & -0.0006 & -0.0003 & 29.959 & 1 & $<0.001$ \\
\hline $\begin{array}{l}\text { Cross-sectional area of the right caudate } \\
\text { head }\left(\mathrm{mm}^{2}\right)\end{array}$ & -0.002 & 0.0028 & -0.008 & 0.003 & 0.695 & 1 & 0.404 \\
\hline (Scale) & $0.046 \mathrm{a}$ & & & & & & \\
\hline
\end{tabular}

BPRS: Brief Psychiatric Rating Scale

Dependent Variable: BPRS score

a. Calculation based on thePearson's Chi-Squared test.

Table 5. Examination of the dependency of the intensity of psychotic manifestations from the largest cross section perimeter of the right caudate nucleus head

\begin{tabular}{|c|c|c|c|c|c|c|c|}
\hline \multicolumn{8}{|c|}{ Parameter Estimates } \\
\hline \multirow{2}{*}{ Parameter } & \multirow{2}{*}{ B } & \multirow{2}{*}{$\begin{array}{l}\text { Standard } \\
\text { Error }\end{array}$} & \multicolumn{2}{|c|}{$\begin{array}{l}\text { 95\% Wald Confidence } \\
\text { Interval }\end{array}$} & \multicolumn{3}{|c|}{ Hypothesis Test } \\
\hline & & & Lower & Upper & $\begin{array}{c}\text { Wald } \\
\text { Chi-Square }\end{array}$ & df & $\mathrm{p}$ \\
\hline (Intercept) & 4.906 & 0.2470 & 4.421 & 5.390 & 394.367 & 1 & $<0.001$ \\
\hline Years & -0.0005 & 0.00008 & -0.0006 & -0.0003 & 34.615 & 1 & $<0.001$ \\
\hline $\begin{array}{l}\text { Cross-sectional perimeter of the right } \\
\text { caudate head }(\mathrm{mm})\end{array}$ & -0.013 & 0.0052 & -0.023 & -0.003 & 6.448 & 1 & 0.011 \\
\hline (Scale) & $0.040^{\mathrm{a}}$ & & & & & & \\
\hline
\end{tabular}

BPRS: Brief Psychiatric Rating Scale

Dependent Variable: BPRS score

a. Calculation based on thePearson's Chi-Squared test.

the largest cross section of the right caudate nucleus head we found greater intensity of psychotic manifestations in younger persons(regression coefficient $\mathrm{B}=$ $-0.0005, \mathrm{p}<0.001)$ with smaller caudate head perimeter (regression coefficient $\mathrm{B}=-0.013, \mathrm{p}=0.011)$ (Table $5)$. For the examination of statistical significance, the generalized linear model of the subclass gamma with the log link (robust estimator) was used.

\section{DISCUSSION}

In terms of morphology of caudate nucleus and its association with psychotic manifestations in schizophrenia results in the literature are different. Thus, for example, Rich AM et al. did not observe the morphometric caudate nucleus alterations in patients with chronic and early schizophrenia (6). Brugger SP et. Howes OD in meta-analysis also did not indicate the modified caudate nucleus in patients with the first episode of schizophrenia (7). Authors(8) came up with a similar conclusion. On the other hand, Ebdrup BH et al. indicated a reduction in volume and smaller caudate nucleus in patients with the first episode of schizophrenia without the use of antipsychotics (9). Also, Stegmayer K et al. in patients with schizophrenia and significant emotional dysregulation indicate the reduction of gray mass in ventral striatum and caudate nucleus (10). Li Y et al. in meta-analysis showed reduction of grey mass of the left caudate nucleus (11), and Brandt GN et Bonelli RM (12) emphasize, besides the reduction of caudate nucleus in the first episode of schizophrenia, to the increased caudate nucleus in chronic phase, as a consequence of the antipsychotic application.

The authors (13) also point out to the smaller caudate nucleus in early schizophrenia in comparison to a healthy population, with a subsequent increase in the 
size of the caudate nucleus after ordering antipsychotic therapy. Zampieri $\mathrm{E}$ et al. emphasize the importance of antipsychotics to the increase of caudate nucleus too (14). However, in this case, different findings are also depicted in the literature. Emsley R et al. do not only challenge the smaller caudate nucleus in patients with early schizophrenia, pointing to their findings of a larger caudate nucleus of schizophrenic patients, but also negating the increase of the caudate nucleus after administration of antipsychotics such as risperidone and flupentixol (15). In support of the aforementioned larger caudate nucleus in patient with schizophrenia refer also the studies $(16,17)$. Regarding the increase of caudate nucleus after ordering antipsychotics, Mouchlianitis $\mathrm{E}$ et al. cited different findings in meta-analysis i.e. three studies where antipsychotic clozapine led to caudate nucleus reduction, not increment (18). However, in the later case, there are literature counterparts that point to the increased metabolism of caudate nucleus after the administration of clozapine (19). So, the issues are not completely settled yet.

In our study, we found a negative correlation between intensity psychotic manifestations from the size of the cross section of caudate nucleus head; on the left brain hemisphere from the both i.e. area and perimeter (Table 2 and 3), and from the perimeter on the right brain side (Table 5). Greater intensity of psychotic manifestations in patients with smaller head size of cauda- te nucleus was also noted by the authors (20). Our finding of the dependence of the intensity of psychotic manifestations on the perimeter of the right caudate head and not from its area speaks in favor of the deformations of the surface of caudate nucleus head in patients with schizophrenia, as indicated by the study (21).

\section{CONCLUSION}

In our research we found that the higher intensity of psychotic manifestations in schizophrenia was accompanied with the smaller area and the perimeter of left caudate head as well as the smaller perimeter of the head of right caudate nucleus. The finding of the correlation between intensity of psychotic manifestations on the perimeter of the right caudate head and not on its area speaks in favor of the caudate head surface deformations as one of the markers of intensity of psychotic manifestations in patients with schizophrenia.

\section{DECLARATION OF INTEREST}

The autors declare that there are no conflicts of interests.

\section{Licensing}

This work is licensed under a Creative Commons Attribution 4.0 International (CC BY 4.0) License.

\title{
Sažetak
}

\section{ANALIZA KORELACIJE MORFOMETRIJSKIH KARAKTERISTIKA GLAVE REPATOG JEDRA I INTENZITETA PSIHOTIČNIH MANIFESTACIJA KOD SHIZOFRENIJE}

\author{
Stojanovic Zlatan, ${ }^{1}$ Stojanovic Vukadinovic Sanja, ${ }^{2}$ Macanovic Gordana ${ }^{3}$ \\ ${ }^{1}$ Univerzitet u Banja Luci, Medicinski fakultet, Zavod za anatomiju, RS, Bosna i Hercegovina \\ ${ }^{2}$ Univerzitetski klinički centar Republike Srpske, Klinika za psihijatriju, Banja Luka, RS, Bosna i Hercegovina \\ ${ }^{3}$ Viša škola za obrazovanje vaspitača, Sremska Mitrovica, Republika Srbija
}

Uvod: Jedan od značajnih funkcionalnih poremećaja centralnog nervnog sistema kod pacijenata sa shizofrenijom je povećana aktivnost mezolimbičkog dopaminergičkog sistema. Preko nigrostrijatnog puta repato jedro je usko funkcionalno povezano sa drugim dopaminergičkim sistemima mozga. Budući da se funkcija nc. Caudatusa naslanja na djelovanje dopamina u mozgu, uloga ove anatomske strukture u patogenezi shizofrenije nije dovoljno razjašnjena. Cilj ovog rada je bio da se ispita da li repato jedro učestvuje u modulaciji intenziteta psihotičnih manifestacija kod shizofrenije. Ispitanici i metode: Istraživanje je obuhvatilo ukupno trideset i jednu osobu obolelu od shizofrenije. Dijagnoza shizofrenije je postavljana na osnovu DSM-IV kriterijuma, a intenzitet psihotičnih manifestacija je procenjivan primenom skale za procenu psihotičnih poremećaja - BPRS (Brief Psychiatric Rating Scale). Veličina glave repatog jedra određivana je na aksijalnim nekontrasnim CT snimcima na površini najvećeg poprečnog preseka primenom AutoCAD 2007 digitalne morfometrije. Statistički podaci su obrađivani u SPSS 16.0 programskom paketu. Statistički zaključci izneseni su na osnovu dvosmernog $\mathrm{p}<0.05$. Rezultati: U ovom istraživanju uočili smo negativnu korelaciju površine i obima preseka leve glave repatog jedra $i$ intenziteta psihotičnih manifestacija (površina: regresioni koeficijent $\mathrm{B}=$ $-0.17, \mathrm{p}=0.050$, obim: regresioni koeficijent $\mathrm{B}=$ 
$-0.010, p=0.012)$. Na desnoj hemisferi mozga uočili smo negativnu korelaciju intenziteta psihotičnih manifestacija samo od obima preseka glave repatog jedra (regresioni koeficijent $\mathrm{B}=-0.013, \mathrm{p}=0.011$ ). Zaključak: U našem istraživanju uočili smo da je veći intenzitet psihotičnih manifestacija kod pacijenata sa shizofrenijom bio praćen manjom površinom i obimom glave levog nc. Caudatusa i manjim obimom

\section{REFERENCES}

1. Marinkovic S, Milisavljevic M, Kostic V. Functional and topographic neuroanatomy.Nauka: Belgrade; 1998.

2. Kalicanin P. Psychiatry. Belgrade: Draslar Partner; 2002.

3. American Psychiatric Association. Diagnostic and statistical manual of mental disorders, fourth edition, text revision. Washington DC: American Psychiatric Association; 2000.

4. Overall JE, Gorham DR. The brief psychiatric rating scale (BPRS). Recent developments in ascertainment and scaling. Psychopharmacol Bull. 1988; 24: 97-99.

5. Stojanovic Z, VukadinovicStojanovic S. Correlation analysis between depressive manifestations and morphological lesion characteristics in patients with stroke. Sanamed 2014; 9(1): 31-40

6. Rich AM, Cho YT, Tang Y, Savic A, Krystal JH, Wang $\mathrm{F}$, et al.Amygdala volume is reduced in early course schizophrenia. Psychiatry Res Neuroimaging. 2016; 250: 50-60.

7. Brugger SP, Howes OD. Heterogeneity and homogeneity of regional brain structure in schizophrenia: A meta-analysis. JAMA Psychiatry. 2017; 74(11): 1104-11.

8. Palaniyappan L, Maayan N, Bergman H, Davenport C, Adams CE, Soares-Weiser K.Voxel-based morphometry for separation of schizophrenia from other types of psychosis in first episode psychosis.Cochrane Database Syst Rev. 2015; 8: CD011021.

9. Ebdrup BH, Glenthrj B, Rasmussen H, Aggernaes B, Langkilde AR, Paulson OB, et al. Hippocampal and caudate volume reductions in antipsychotic-naive first-episode schizophrenia. J Psychiatry Neurosci. 2010; 35(2): 95-104.

10. Stegmayer K, Horn H, Federspiel A, Razavi N, Bracht $\mathrm{T}$, Laimböck K, et al.Ventral striatum gray matter density reduction in patients with schizophrenia and psychotic emotional dysregulation. Neuroimage Clin. 2013; 4: 232-9.

11. Li Y, Li WX, Xie DJ, Wang Y, Cheung EFC, Chan RCK. Grey matter reduction in the caudate nucleus in patients with persistent negative symptoms: An ALE meta-analysis. Schizophr Res. 2018; 19(2): 9-15.

\section{Correspondence to / Autor za korespondenciju}

Zlatan Stojanovic,

University of Banja Luka, Faculty of Medicine,

RS, Bosnia and Herzegovina

email: szlatan@blic.net,

phone: +38765717029 glave desnog kaudatusa. Nalaz zavisnosti intenziteta psihotičnih manifestacija od obima glave desnog kaudatusa, a ne i od površine govori u prilog prisutnih deformacija na površini glave repatog jedra kao jednog od korelata intenziteta psihotičnih manifestacija kod pacijenata sa shizofrenijom.

Ključne reči: nc. caudatus, shizofrenija, analiza, korelacija.

12. Brandt GN, Bonelli RM. Structural neuroimaging of the basal ganglia in schizophrenic patients: a review. Wiener Medizinische Wochenschrift. 2008; 158(3-4): 84-90.

13. Glenthoj A, Glenthoj BY, Mackeprang T, Pagsberg AK, Hemmingsen RP, Jernigan TL, et al. Basal ganglia volumes in drug-naive first-episode schizophrenia patients before and after short-term treatment with either a typical or an atypical antipsychotic drug. Psychiatry Res. 2007; 154(3): 199-208.

14. Zampieri E, Bellani M, Crespo-Facorro B, Brambilla P. Basal ganglia anatomy and schizophrenia: the role of antipsychotic treatment. Epidemiol Psychiatr Sci. 2014; 23(4): 333-6.

15. Emsley R, Asmal L, du Plessis S, Chiliza B, Kidd M, Carr J, et al. Dorsal striatal volumes in never-treated patients with first-episode schizophrenia before and during acute treatment.Schizophr Res. 2015; 169(1-3): 89-94.

16. Staal WG, Hulshoff Pol HE, Schnack HG, Hoogendoorn ML, Jellema K, Kahn RS. Structural brain abnormalities in patients with schizophrenia and their healthy siblings. Am J Psychiatry. 2000; 157(3): 416-21.

17. Cuesta MJ, Lecumberri P, Cabada T, Moreno-Izco L, Ribeiro M, López-Ilundain JM, et al. Basal ganglia and ventricle volume in first-episode psychosis. A family and clinical study. Psychiatry Res. 2017; 269: 90-96.

18. Mouchlianitis E, McCutcheon R, Howes OD3. Brain-imaging studies of treatment-resistant schizophrenia: a systematic review. Lancet Psychiatry. 2016; 3(5): 451-63.

19. Nakajima S, Takeuchi H, Plitman E, Fervaha G, Gerretsen $\mathrm{P}$, Caravaggio F, et al. Neuroimaging findings in treatment-resistant schizophrenia: A systematic review: Lack of neuroimaging correlates of treatment-resistant schizophrenia. Schizophr Res. 2015; 164 (1-3): 164-75.

20. Tao H, Wong GH, Zhang H, Zhou Y, Xue Z, Shan B, et al. Grey matter morphological anomalies in the caudate head in first-episode psychosis patients with delusions of reference. Psychiatry Res. 2015; 233(1): 57-63.

21. Mamah D, Alpert KI, Barch DM, Csernansky JG, Wang L. Subcortical neuromorphometry in schizophrenia spectrum and bipolar disorders. Neuroimage Clin. 2016; 11: 276-86. 